\title{
CSR ACTIVITIES AND CONSUMER LOYALTY: THE EFFECT OF THE TYPE OF PUBLICIZING MEDIUM
}

\author{
Pere MERCADÉ-MELÉ ${ }^{1}$, Sebastian MOLINILLO ${ }^{2 *(\mathbb{D})}$, \\ Antonio FERNÁNDEZ-MORALES ${ }^{3}$ (iD), \\ Lucia PORCU ${ }^{4}$ (D) \\ ${ }^{1,3}$ Department of Statistics and Econometrics, Faculty of Economics and Business, \\ University of Malaga, Campus El Ejido s/n, 29071 Malaga, Spain \\ ${ }^{2}$ Department of Business Management, Faculty of Economics and Business, \\ University of Malaga, Campus El Ejido s/n, 29071 Malaga, Spain \\ ${ }^{4}$ Department of Marketing and Market Research, Faculty of Economics and Business, \\ University of Granada, Campus La Cartuja s/n, 18071 Granada, Spain
}

Received 13 October 2017; accepted 07 May 2018

\begin{abstract}
This research develops a model to predict the effect of advertising a socially responsible activity on perceived corporate social responsibility (CSR) and its influence on consumer loyalty. It examines the relationships between company-cause congruence, corporate credibility, altruism attribution and perceived CSR, and CSR with consumer loyalty, and analyzes the moderating effect of the type of communication medium (i.e. traditional medium vs. social medium). This study is original because it fills the gap in the CSR communication literature in the evaluation of how the use of one or another type of medium to advertise a cause related marketing activity influences the effect of perceived CSR on consumer loyalty. An empirical study was conducted with two samples of consumers, each of which was exposed to the same advertisement, inserted in either a newspaper or posted on a social network. Data were analyzed using structural equation modeling. The results carry implications for CSR activities and communications management as they validate the proposed model that integrates the antecedents of perceived CSR and its influence on loyalty, and show that the traditional medium model has a better fit and its overall effect is greater than the social medium model. From a practical perspective, this study has several implications regarding the importance of communicating CSR activities.
\end{abstract}

Keywords: CSR, corporate communication, congruence, credibility, altruism attribution, loyalty, retail.

JEL Classification: M14, M31.

*Corresponding author. E-mail: smolinillo@uma.es

This is an Open Access article distributed under the terms of the Creative Commons Attribution License (http://creativecommons. org/licenses/by/4.0/), which permits unrestricted use, distribution, and reproduction in any medium, provided the original author and source are credited. 


\section{Introduction}

In recent years, corporate social responsibility (CSR) has been much debated and seen as an important subject in the fields of business management and academic research (Wang, Tong, Takeuchi, \& George, 2016). One of the topics of interest has been the definition of the limits of the CSR concept itself. Within the context of this study, CSR is defined as the management of the concerns of the stakeholders about responsible and irresponsible acts related to environmental, ethical and social phenomena, in a fashion that generates corporate benefits (Vaaland, Heide, \& Grønhaug, 2008).

The economic crisis has created a growing interest in CSR, not only due to increased societal demands, but also due to internal pressure within companies to reduce budgets in response to doubts about the returns CSR generates (Sen, Du, \& Bhattacharya, 2016). Although some authors have shown a positive relationship between CSR initiatives and market behavior toward the company (Marín, Cuestas, \& Román, 2016), how and when CSR actions produce favorable and unfavorable consumer reactions remain unknown (Leonidou \& Skarmeas, 2017). However, many companies have adopted a strategic approach and allocated unprecedented resources and efforts to CSR (Porter \& Kramer, 2011). Therefore, the organizations must be proactive in gathering information about consumers' interests (Susnienè \& Purvinis, 2015). Moreover, from the firms' perspective, knowledge of how consumers perceive CSR activities should be improved so that the CSR activities can be more effectively publicized (Wang et al., 2016).

Hence, one of the most important issues regarding CSR is how to publicize the activities carried out (Korschun \& Du, 2013; Green \& Peloza, 2015). In their study on CSR communication, Ingenhoff and Sommer (2011) found that hardly any of the stakeholders questioned were able to recall a specific CSR activity carried out by an organization. The authors suggest that this phenomenon might be due to the fact that such 'pull-information' needs to be actively searched for and that companies are not succeeding in effectively communicating their CSR activities. Companies generally use different communication media and tools to disseminate CSR-related information, such as annual reports, press releases, advertisements, websites and social reports. During the recent period of crisis, the use of advertising increased among the marketing communication tools used to publicize CSR activities (Green \& Peloza, 2015). More importantly, the extant literature suggests that the same advertisement delivered through different communication media can persuade or, conversely, cause skepticism among consumers (Maignan \& Ferrell, 2004; Jeong, Paek, \& Lee, 2013; Sen et al., 2016). In this regard, Du, Bhattacharya and Sen (2010) suggested that the less control the firm has over the communication medium, the more credible will be seen the socially responsible action, and vice versa, corporate sources triggering more skepticism than non-corporate sources. Some authors argue that traditional media such as newspapers, television, magazines and radio are more credible than the Internet and social media (Johnson \& Kaye, 1998; Moore \& Rodgers, 2005). However, despite the importance of the medium in communications, an in-depth analysis of the moderating effect of the type of medium employed on CSR activities has yet to be carried out.

The aim of companies in communicating CSR is to increase transparency, brand equity, reputation and legitimacy, or to draw favorable comparisons with competitors, among other 
things (Herzig \& Schaltegger, 2006). With regard to the effects of companies' socially responsible activities on the brand, preliminary studies have shown that they positively influence brand loyalty (Du, Bhattacharya, \& Sen, 2007; Walsh \& Bartikowski, 2013), but we find no evidence that the effect of the type of communication medium on that relationship has been assessed in previous studies.

Therefore, the aim of this study is to help to broaden knowledge about the effect of advertising a socially responsible activity on perceived corporate social responsibility (CSR), and its influence on consumer loyalty. More specifically, this research has three objectives: (1) To conduct an empirical analysis of the impact of the congruency of the socially responsible activity, corporate credibility and attribution of altruistic motivation on perceived CSR; (2) To analyze the relationship of the CSR with loyalty intention; and (3) To assess the moderating effect of the communication medium used to publicize the socially responsible activity. To do this, data were collected through face-to-face interviews with 623 people living in three Spanish provinces, and this was analyzed using structural equation modeling.

\section{Theoretical background and hypotheses development}

\subsection{Conceptual framework}

The conceptual framework of this study is based on the Hierarchy of Effects Model (Lavidge \& Steiner, 1961) and the Associative Learning Principles (Shimp, Stuart, \& Engle, 1991). The Hierarchy of Effects Model describes three stages of consumer behavior: (1) cognitive, referring to the client's knowledge; (2) affective, referring to feelings and emotions; and (3) conative, referring to the intentions and actions of the consumer's behavior. This model, which can be synthesized as awareness, attitudes and intentions, is valid to describe the logical process of how an individual passes from ignorance of a company's CSR activities to becoming an advocate of the company's CSR activities (Murray \& Vogel, 1997). Companies communicate their CSR activities, thus promoting the consumer's knowledge of these activities, which forms attitudes and feelings in the consumer that affects their behaviors (e.g. repurchase and recommendation) (Pérez \& Rodríguez Del Bosque, 2015).

On the other hand, Shimp et al. (1991) describe the process by which consumers generate thoughts and feelings towards brands based on their association with ideas, concepts or facts, as Associative Learning. Companies want to be linked to the socially responsible activities they carry out in order to benefit from the mechanisms of Associative Learning (Till \& Nowak, 2000) and because these links will position them as socially responsible companies (Sen et al., 2016). In this regard, Martindale (1991) suggested that long-term memory is a network of nodes, which represent our comprehensive set of information and knowledge about companies, brands and various causes and these are connected through associative links. With this premise, companies attempt to build an associative link between the company and the desired/noble cause in order to restructure their consumers' associative networks. Thus, the effective use of these basic Associative Learning principles enables companies to leverage their investment in cause-related marketing efforts.

The Hierarchy of Effects model was applied prior to the study of the consumer response to the socially responsible activities of the companies, identifying company-cause congruence, 
corporate credibility and motivational attribution as important variables of the process (Rifon, Choi, Trimble, \& Li, 2004; Bigné, Currás, \& Aldás, 2012). Our research will analyze how consumers perceive a socially responsible activity through the relationships between congruence, corporate credibility, altruism attribution and CSR perception and its influence on loyalty intention. In addition, we will examine the role played by the communication medium utilized to advertise the CSR activities, by analyzing the moderating role of the use of traditional vs. social media.

\subsection{Congruence and corporate credibility}

The congruence between the company and its socially responsible activity refers to the consumer's perception of the similarity or coherence between the company (its image) and the socially responsible activity it carries out (Varadarajan \& Menon, 1988). Congruence theory suggests that, where there is a good fit between a company's activities and its social action, the consumer has a better attitude toward the company (Lafferty, 2007). Researchers recommend that companies support social causes that match the image of their brand, product lines, positioning or target market (Marín et al., 2016; Wang et al., 2016). For example, consumers consider it more coherent for a food company to donate food to disadvantaged people than to donate money to a museum.

A company's credibility in respect of its socially responsible activities is defined as the degree to which consumers perceive the company as acting in good faith and possessing the ability and experience needed to carry out the activities (Bigné, Currás, \& Sánchez, 2009). Companies with a high degree of coherence between their core activities and their socially responsible activities are more credible (Rifon et al., 2004). In this sense, Bigné et al. (2012) argued that when coherence is high, consumers are less skeptical about companies, consider them more credible and need less cognitive effort to arrive at their judgment. In turn, Becker-Olsen, Cudmore and Hill (2006) suggested that companies whose socially responsible activities are aligned with their business activities will be more successful, as this perceived alignment will minimize the risk that the consumer will believe that the companies are acting through self-interest and, therefore, will be more credible. In this case, consumers will make causal inferences about the activities they observe and will regard the advertisements as sincere and credible (Lafferty, 2007; Mercadé-Melé, Molinillo, \& Fernández-Morales, 2017). This leads to the following research hypothesis:

H1: Company-social cause congruence has a direct and positive impact on corporate credibility.

\subsection{Congruence and CSR}

Companies want to be linked to the socially responsible activities they undertake in order to provoke Associative Learning (Till \& Nowak, 2000) and to position themselves as socially responsible (Sen et al., 2016). When the core activity of a company is highly integrated with its socially responsible activities, consumers take a favorable attitude toward the organization (Nan \& Heo, 2007). Recent studies have shown a direct relationship between fit and perceived CSR (Du et al., 2007; Bigné et al., 2012; Marín et al., 2016). Greater congruence between the 
company and its socially responsible activities results in a better consumer image of the CSR (Bigné et al., 2012). Conversely, low-fit CSR activities negatively impact on the consumer's beliefs and his or her perception of a company's CSR (Becker-Olsen et al., 2006). Peloza and Shang (2011) showed that consumers prefer products from firms with product related CSR over products from firms undertaking other, unrelated philanthropic or business practices. Along the same lines, Barone, Norman and Miyazaki (2007) concluded that high levels of congruence between a retailer and its social cause improves the consumer's evaluation of the firm. Therefore, the following hypothesis is formulated:

H2: Company-social cause congruence has a direct, positive impact on perceived CSR.

\subsection{Congruence and altruism attribution}

Company-socially responsible activity congruence can also influence the attribution of altruistic motives to the company. According to Attribution Theory (Kelley, 1973), individuals make inferences based on the available information to identify the causes of events, and incorporate those reasons into their decision making processes about what actions to take to achieve the continuity or otherwise of these events. The attribution of motives is the outcome of a consumer's cognitive process when considering the motives behind a company's socially responsible activity (Skarmeas \& Leondiou, 2013). Consumers make deductions about the firm's actual motives for carrying out the activities (Folkes, 1988). Consumers wonder whether companies are sincere and genuine in their efforts related to socially responsible activities (Ellen, Webb, \& Mohr, 2006; Leonidou \& Skarmeas, 2017) or, whether, on the contrary, they are acting opportunistically and solely aim at making profits (Becker-Olsen et al., 2006). Companies seek to be linked to symbolic values (such as altruism or civic-mindedness) in order to be well regarded by consumers (Bigné et al., 2009).

Company-social cause fit has a direct, positive impact on the attribution of altruistic motives (Rifon et al., 2004; Becker-Olsen et al., 2006; Ellen et al., 2006; Marín et al., 2016). If congruence is low, consumers have pre-existing judgments that consider that socially responsible actions carried out by companies are self-serving or due to profit making motives (Donia \& Sirsly, 2016). Conversely, with high firm-cause congruence, consumers are less skeptical about the company's intentions and do not attribute self-serving motives to it (Bigné et al., 2012). Consequently, the greater the congruence between the socially responsible activity and the company, the fewer arguments consumers will have against the activity and the greater will be their altruism attribution (Du et al., 2007). Consequently, the following hypothesis is formulated:

H3: Company-social cause congruence has a direct and positive impact on the attribution of altruistic motives to a company.

\subsection{Corporate credibility and CSR}

Companies must communicate their CSR policies to discover whether their activities are credible (Marín et al., 2016). A company's credibility allows it to minimize negative judgments directed toward it and provides confidence to consumers (Varadarajan \& Menon, 1988; Rifon et al., 2004). 
If the company manages to portray the socially responsible activity as credible, the consumer will have a better perception of the CSR (Ellen et al., 2006). Due to this credibility, consumers are less skeptical about the socially responsible activities companies engage in and this improves their CSR image (Korschun, Bhattacharya, \& Swain, 2014). Therefore, the following hypothesis is formulated:

H4: The credibility of a company has a direct and positive impact on CSR.

\subsection{Altruism attribution and CSR}

The perception of CSR will depend on the attributions consumers make to companies with regard to the motives behind the socially responsible activities they undertake (Berens, van Riel, \& van Bruggen, 2005; Barone et al., 2007; Marín et al., 2016). Attribution Theory attempts to explain consumers' cognitive processes when considering the reasons that companies have for engaging in socially responsible activities (Becker-Olsen et al., 2006; Leonidou \& Skarmeas, 2017; Wang et al., 2016). When consumers attribute sincere motives to the activities, CSR has a positive impact on consumers (Bigné et al., 2012). The attribution of altruism to the company improves the perception of its CSR (Ellen et al., 2006; Du et al., 2007; Ioannou \& Serfaeim, 2015). Conversely, a negative perception of the company's motives reduces the impact of the social cause and has a negative impact on the image of the CSR activity (Barone et al., 2007). Accordingly, the attribution of altruistic motives to the company generates a positive image of its CSR (Rifon et al., 2004; Ellen et al., 2006; Bigné et al., 2012; Marín et al., 2016; Wang et al., 2016), which leads to the following hypothesis:

H5: The attribution of altruistic motives to a firm has a direct and positive impact on the perception of its CSR.

\subsection{Relationship of CSR with loyalty intention}

CSR causes cognitive and affective effects (beliefs, attitudes) in consumers, such as the purchase of a product and loyalty (Walsh \& Bartikowski, 2013; Wang et al., 2016). Loyalty intention refer to the consumers' internal willingness to commit to the firm (Oliver, 1999) and his or her predisposition to maintain their consumption habits (Nguyen \& Leblanc, 2001). Sometimes, loyalty is represented by the number of repurchases made by the consumer during a period of time. If a consumer is loyal, it means that he or she is predisposed to repurchasing a particular product or service (Sirohi, McLaughlin, \& Wittink, 1998).

Corporate social performance influences consumer-firm emotional attachment, which has a positive impact on loyalty intention (Vlachos, 2012). Engaging in CSR-related practices can generate a relationship of trust between a company and its clients and encourage customer loyalty (Oppewal, Alexander, \& Sullivan, 2006). A positive consumer attitude resulting from the socially responsible activities undertaken by firms is translated into greater consumer loyalty (Walsh \& Bartikowski, 2013). Du et al. (2007) showed that better integration of CSR activities into a firm's competitive strategies has a positive impact on its credibility and on consumers' long-term loyalty intention. Therefore, the following hypothesis is formulated:

H6: CSR has a direct and positive impact on consumers' loyalty intention. 


\subsection{Moderating effect of the communication medium}

The type of medium used to communicate the socially responsible activity influences the consumer's response (Jeong et al., 2013; Korschun \& Du, 2013). Accordingly, the same message can have positive or negative effects on consumers depending on the communication medium used to convey it (Leonidou \& Skarmeas, 2017). Despite the fact that both marketing communications scholars and practitioners have widely acknowledged the crucial role of the type of media used on consumers' perceptions, there is still a dearth of research on how it influences perceived CSR. Accordingly, Golob, Podnar, Elving, Ellerup Nielsen and Thomsen (2013) highlights that there is no record to date of any empirical and solid analysis of the moderating effect of the communication medium on the perception of CSR. However, some theoretical studies suggest that this research gap has attracted attention in the academic arena. For instance, Maignan and Ferrell (2004) conducted a conceptual analysis of the moderating effect of communication about CSR on stakeholders' identification with the firm, but they did not distinguish between the different types of communications media. In another conceptual paper, Du et al. (2010) highlighted the need for companies to communicate CSR more effectively to stakeholders and developed a conceptual framework where message content (what to communicate) and communication channels (where to communicate) are described as the two pillars of effective CSR communication. These authors concluded that the less control the organization has over the communication medium, the more that information about CSR activities will be perceived as reliable, corporate sources triggering more skepticism than non-corporate sources. Similarly, Skard and Thorbjørnsen (2014) showed that a non-corporate source (i.e. publicity) generates more positive evaluations for a brand than a corporate source (i.e. advertisement) where the information source has a positive reputation.

Among the wide range of marketing communications tools that firms may use in order to communicate their CSR activities, the use of advertising has increased in recent years (Green \& Peloza, 2015). Two key barriers to advertising effectiveness emerged from the study performed by Kelly, Kerr and Drennan (2010): relevance and credibility. Johnson and Kaye (1998) showed that advertising has less credibility when it is received via a medium that is not perceived as trustworthy. Moore and Rodgers (2005) examined the differences in consumers' perceptions of advertising credibility in five media (newspapers, television, radio, magazines and the Internet) and demonstrated that skepticism about advertising was highest for new media and lowest for print media. Their findings also suggested that newspaper advertisements were the most credible, while online advertisements were the least credible. Similarly, Kelly et al. (2010) found that consumers are skeptical regarding online social networking sites as credible advertising media. In regard to trustworthiness, the proliferation of online advertisement formats has not damaged trust in traditional advertising channels, TV advertisements (63\% of respondents), and advertisements in newspapers (60\%) and in magazines (58\%) remaining trusted formats. On the other hand, trust in online and mobile advertisements is stable since 2013, almost half of the global respondents stating they trust online video advertisements (48\%) and advertisements on social networks (46\%) (Nielsen, 2015). 
In terms of choosing the type of communication medium to advertise CSR, two different categories are identified: (1) traditional media (e.g., newspapers, radio, and television) and (2) social media (e.g., social networks, blogs) (Korschun \& Du, 2013). The Internet allows firms to publicize more current information less expensively, which has made it one of their main communication tools for CSR activities (Wanderley, Lucian, Farache, \& de Sousa Filho, 2008). Similarly, Pollach (2005) stated that digital media have more advantages than traditional media. First, the Internet enables companies to deliver a great number of messages to potential targets. Second, as a 'pull' medium, audiences have more control over the messages they want to see and will process online information more effectively than that sent through traditional media. Third, the information is not assessed and filtered by gatekeepers, as is the case with newspapers and TV, but remains under the control of the company. Fourth, interactivity is the 'hallmark' of digital media and provides companies with opportunities to gather more information about their stakeholders. Other beneficial assets Pollach (2005) considered to derive from the use of web-based media are the credibility and value of the content. Nevertheless, according to Jahdi and Acikdilli (2009), Pollach (2005) failed to acknowledge that it can be extremely difficult for consumers to untangle signs of trust, credibility and reliability from the complex network of numerous websites. More importantly, the lack of gatekeepers/filters generates more concerns regarding the trustworthiness of web-based information, especially when it comes to creating a socially responsible corporate image. Jahdi and Acikdilli (2009) highlighted that source credibility and reliability are essential requirements for any communication tool and media to be effective and a holistic and integrated approach is needed to ensure successful CSR communications, advertising having the potential to contribute greatly to promoting an ethical corporate image, which is positively related to customer-based performance indicators (i.e. customer satisfaction and loyalty).

Recent studies have shed more light on the role of certain media in CSR communications processes, indicating that traditional media have long represented the most common way of advertising CSR activities, given that they are highly credible and trustworthy (Saat \& Selamat, 2014). Accordingly, firms have been making increasing use of social media, especially social networks, in their communication strategies (Kent \& Taylor, 2016), though rarely to communicate their CSR activities (Berg \& Sheehan, 2014). As might be noted, the theoretical background to this research issue is still developing and further clarification is very much needed. However, in light of the above rationale, it seems reasonable to assume that using traditional as opposed to social media to report on organizational CSR activities exerts certain influence on consumers' perceptions and, therefore, their loyal intentions. More specifically, we posit that the media type will moderate the relationship between congruence and CSR and between CSR and loyalty, due to the specific features (as mentioned before) of the medium used to advertise the organization's CSR achievements. Thus, the following hypotheses are formulated:

H7: The impact of communication medium used to advertise CSR activities on the relationships between congruence, corporate credibility, attribution and CSR, and between this latter and loyalty, is higher for traditional than for social media.

H7.1: The impact of company-social cause congruence on corporate credibility is significantly higher for traditional than for social media. 
H7.2: The impact of company-social cause congruence on perceived CSR is significantly higher for traditional than for social media.

H7.3: The impact of company-social cause congruence on the attribution of altruistic motives to a company is significantly higher for traditional than for social media.

H7.4: The impact of the credibility of the company on perceived CSR is significantly higher for traditional than for social media.

H7.5: The impact of altruistic motives to the firm on perceived CSR is significantly higher for traditional than for social media.

H7.6: The impact of perceived CSR on consumers' loyalty intention is significantly higher for traditional than for social media.

\subsection{Research model}

The theoretical model proposed in this study integrates five constructs and six hypotheses, rising to twelve when evaluating the moderating effect of the communication medium (Figure 1). A descriptive table of previous studies is included in Appendix to show the originality of this model. The contribution of this work is original because no previous study has been found that has discussed and tested all of the relationships of the proposed research model, or evaluated the moderating effect of the media considered here in a similar context.

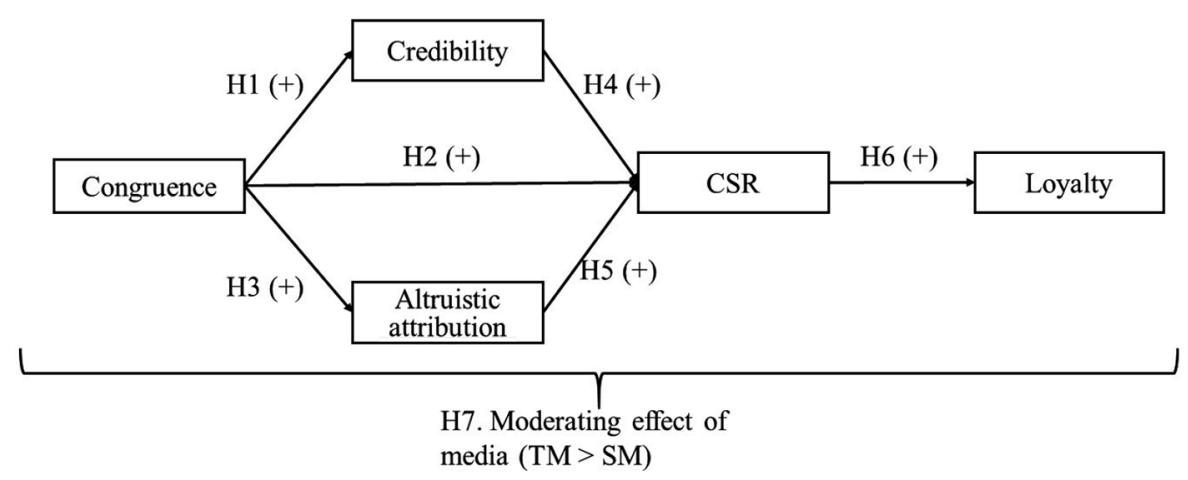

Note: TM: Traditional media; SM: Social Media.

Figure 1. Research model

\section{Methodology}

\subsection{Procedure}

Experimental research with two independent consumer samples was carried out to evaluate the theoretical model. Each sample was shown a different stimulus: (1) An advertisement inserted in a newspaper; and (2) the same advertisement inserted in a social network. In the advertisement a retail food company was linked to a non-profit organization (NPO) in a cause-related marketing simulation. An advertisement was designed for each of the six retail 
food companies with the highest market shares in Spain: Mercadona, Dia, Carrefour, Eroski, Alcampo, and Lidl (Kantar Worldpanel, 2015). There is a positive relationship between the firms' CSR performances and their size (Agudo, Gargallo, \& Salvador, 2015). Companies in this sector are making large investments in CSR programs (Walsh \& Bartikowski, 2013) and sell products that are very sensitive to companies' CSR. However, few studies on CSR in this sector have to date been carried out in Spain (Mercadé, Molinillo, \& Fernández, 2014).

The NPO and the socially responsible activity were chosen based on a focus group of 10 people who habitually buy food products in hypermarkets and/or supermarkets. A food bank organization was chosen as it was considered to be one of the organizations obviously linked to the fight to eliminate hunger. The socially responsible activity chosen was a donation linked to food sales as it was considered to be an activity that was a good fit for the food retail business. Specifically, the advertisement designed was the following: "C (company name) commits to donating $5 \%$ of milk sales to the food bank (NPO name)".

In order to make the experiment more realistic, for the newspaper the advertisement was inserted on paper on the reproduction of a front page; for the online scenario it was shown on a tablet. The newspaper 20Minutos was chosen because it has the largest daily paper print run (Información y Control de Publicaciones, 2016). Facebook was the social media chosen because $94 \%$ of social media users in Spain have a profile on the network (Interactive Advertising Bureau [IAB], 2015). The advertisement was adapted to the format of the two media chosen, but the images, expressions and typography used were maintained regardless of the medium used.

\subsection{Instrumentation}

Data were gathered through a survey. The questionnaire consisted of three parts. The first was an introduction with screening questions, to discover the rate of food purchase from the different stores chosen for the research. The second part (the main section of the questionnaire) presented the advertisement using the design created for whichever store the respondent had identified as his or her most frequent shopping destination and posed the questions needed to test the model's hypotheses. The advertisement in the 20Minutos newspaper was presented to Sample 1 and that in the company's Facebook social network profile was shown to Sample 2. Finally, the third part asked questions to classify respondents. The questionnaire was tested using a pre-test conducted on a sample of 25 people, which made it possible to improve and clarify the wording of the questions.

\subsection{Variable measurement}

The nature of epistemological relationships is reflective as they are more suitable for defining personality and attitudinal features (Fornell \& Bookstein, 1982). The latent variables were measured based on multi-attribute scales because of their usefulness in obtaining ratings of psychological variables (Iacobucci \& Churchill, 2010). Specifically, semantic differential scales and seven-point Likert scales, where 1 means "totally disagree" and 7 means "totally agree", were used. The measurement instruments used in this research have been validated in previous papers. In particular, corporate credibility was measured based on the scale validated 
by Bigné et al. (2012) and the guidelines of McWilliams and Siegel (2001). Attribution of altruism was measured based on the scale validated by Ellen et al. (2006) and Skarmeas and Leonidou (2013). CSR was measured based on five items from the scale validated by Berens et al. (2005) and Walsh and Bartikowski (2013). Loyalty intention were measured based on the scale of Walsh and Bartikowski (2013). Congruence was measured based on a five-item, seven-point differential semantic scale adapted from Rifon et al. (2004), Becker-Olsen et al. (2006) and Bigné et al. (2012).

\subsection{Sample}

The target population for the study was people from 18 to 65 years of age residing in Spain who had frequently shopped in a supermarket or hypermarket in the last year. In order to increase the representativeness of the sample, sampling was done in three provinces in different Spanish autonomous regions. The method for selecting the sample was geographic quota sampling (405 in Barcelona, 144 in Malaga and 74 in Zaragoza) and gender (290 men and 333 women) in an intercept approach. Fieldwork was carried out from June to September 2015. The size of the sample was 623 valid surveys, 311 for the traditional medium and 312 for the virtual medium. Table 1 shows the socio-demographic characteristics of the sample.

Table 1. Socio-demographic characteristics

\begin{tabular}{|l|c|c|c|c|}
\hline \multicolumn{1}{|c|}{ Variable } & Values & $\begin{array}{c}\text { Total } \\
(\mathrm{n}=623)\end{array}$ & $\begin{array}{c}\mathrm{TM} \\
(\mathrm{n}=311)\end{array}$ & $\begin{array}{c}\text { SM } \\
(\mathrm{n}=312)\end{array}$ \\
\hline \multirow{3}{*}{ Gender } & Male & $46.5 \%$ & $46.6 \%$ & $46.5 \%$ \\
\cline { 2 - 5 } & Female & $53.5 \%$ & $53.4 \%$ & $53.5 \%$ \\
\hline \multirow{3}{*}{ Age } & $18-30$ & $20.2 \%$ & $18.7 \%$ & $21.8 \%$ \\
\cline { 2 - 5 } & $31-40$ & $25.8 \%$ & $24.4 \%$ & $27.3 \%$ \\
\cline { 2 - 5 } & $41-50$ & $30.8 \%$ & $29.6 \%$ & $32.1 \%$ \\
\hline Residence & $51-65$ & $23.1 \%$ & $27.3 \%$ & $18.9 \%$ \\
\cline { 2 - 5 } & Barcelona & $65.0 \%$ & $64.9 \%$ & $65.1 \%$ \\
\cline { 2 - 5 } & Malaga & $23.1 \%$ & $22.8 \%$ & $23.4 \%$ \\
\cline { 2 - 5 } & Zaragoza & $11.9 \%$ & $12.3 \%$ & $11.5 \%$ \\
\hline
\end{tabular}

Note: TM: Traditional media; SM: Social media.

\section{Results}

The recommendations of Anderson and Gerbin (1988) were followed for evaluating the research model. The software used for the estimate is STATA 14. First, an analysis of the goodness of fit of the measurement model was made using confirmatory factor analysis (CFA) and, once the psychometric properties were fulfilled, structural relationships were included through structural equation modeling (SEM). SEM has become a power multivariate analysis tool used throughout the social sciences (Fornell \& Bookstein, 1982). In addition, multigroup analysis (MGA) was applied to evaluate the moderating effect of the media. 


\subsection{Evaluation of the psychometric properties of the measurement model}

In order to have a comprehensive assessment of the psychometric properties of our model, and to test the validity of the sample data used in this study, we have performed several tests, described in this section.

First, to assess the possible non-bias error, we performed mean difference tests for all the items in the model between the subsample comprised of the respondents who answered all the questions (included and not included in the model) and the subsample who did not answer questions corresponding to items not included in the model (10.4\% of the sample size). The results indicate that the differences were not statistically significant (for $\alpha=0.05$ ) and, thus, we do not consider that non-response bias in this survey is a serious problem affecting our conclusions.

Moreover, we used two methods to test for CMV bias. Firstly, according to Harman's single factor method, the first factor obtained by applying an exploratory factor analysis to all the manifest variables accounted for $34 \%$ of the total variance, which is below the common threshold of $50 \%$. The common latent factor method was also used to test the presence of CMV, connecting a common latent factor to all the observed variables, maintaining the relationships between the latent constructs. The estimated common variance from this analysis was also less than $50 \%$ (41.8\%). Hence, we can assume our data set is not subject to serious CMV bias.

The results of the CFA of the general model are shown below, in order to evaluate its psychometric properties using the principal measures of reliability, validity and goodnessof-fit statistics (Table 2).

Table 2. Confirmatory psychometric properties

\begin{tabular}{|c|c|c|c|c|c|c|}
\hline Factor & Items & Loads & $\begin{array}{l}\text { Average } \\
\text { Loads }\end{array}$ & $\alpha$ & AVE & CR \\
\hline \multirow[t]{5}{*}{ Congruence } & CON1 & 0.935 & \multirow{5}{*}{0.939} & \multirow{5}{*}{0.975} & \multirow{5}{*}{0.882} & \multirow{5}{*}{0.974} \\
\hline & CON2 & 0.920 & & & & \\
\hline & CON3 & 0.950 & & & & \\
\hline & CON4 & 0.956 & & & & \\
\hline & CON5 & 0.933 & & & & \\
\hline \multirow[t]{5}{*}{ Credibility } & CRE1 & 0.906 & \multirow{5}{*}{0.888} & \multirow{5}{*}{0.950} & \multirow{5}{*}{0.792} & \multirow{5}{*}{0.950} \\
\hline & CRE2 & 0.921 & & & & \\
\hline & CRE3 & 0.771 & & & & \\
\hline & CRE4 & 0.906 & & & & \\
\hline & CRE5 & 0.934 & & & & \\
\hline \multirow{5}{*}{$\begin{array}{l}\text { Altruism } \\
\text { Attribution }\end{array}$} & ALT1 & 0.876 & \multirow{5}{*}{0.854} & \multirow{5}{*}{0.934} & \multirow{5}{*}{0.729} & \multirow{5}{*}{0.931} \\
\hline & ALT2 & 0.877 & & & & \\
\hline & ALT3 & 0.827 & & & & \\
\hline & ALT4 & 0.852 & & & & \\
\hline & ALT5 & 0.836 & & & & \\
\hline
\end{tabular}


End of Table 2

\begin{tabular}{|c|c|c|c|c|c|c|}
\hline Factor & Items & Loads & $\begin{array}{l}\text { Average } \\
\text { Loads }\end{array}$ & $\alpha$ & AVE & CR \\
\hline \multirow[t]{5}{*}{ CSR } & CRS1 & 0.814 & \multirow{5}{*}{0.838} & \multirow{5}{*}{0.925} & \multirow{5}{*}{0.704} & \multirow{5}{*}{0.922} \\
\hline & CSR2 & 0.871 & & & & \\
\hline & CRS3 & 0.832 & & & & \\
\hline & CSR4 & 0.785 & & & & \\
\hline & CRS5 & 0.888 & & & & \\
\hline \multirow[t]{5}{*}{ Loyalty intention } & LOY1 & 0.898 & \multirow{5}{*}{0.807} & \multirow{5}{*}{0.900} & \multirow{5}{*}{0.660} & \multirow{5}{*}{0.905} \\
\hline & LOY2 & 0.884 & & & & \\
\hline & LOY3 & 0.749 & & & & \\
\hline & LOY4 & 0.842 & & & & \\
\hline & LOY5 & 0.664 & & & & \\
\hline \multicolumn{7}{|c|}{ Higher IC Correlations (Congruence-Credibility): $(0.805-0.860)$} \\
\hline \multirow{2}{*}{$\begin{array}{l}S-B \chi^{2}=889.8 \\
(p=0.000)\end{array}$} & \multicolumn{2}{|c|}{ CFI } & \multicolumn{2}{|c|}{ TLI } & \multicolumn{2}{|c|}{ RMSEA } \\
\hline & \multicolumn{2}{|c|}{0.951} & \multicolumn{2}{|c|}{0.945} & \multicolumn{2}{|c|}{0.061} \\
\hline
\end{tabular}

Cronbach's Alpha ( $\alpha$ ), the Composite Reliability (CR) and the Average Variance Extracted (AVE) show appropriate values. Cronbach's Alpha is greater than 0.7 (Cronbach, 1951), the AVE is greater than 0.5 and the CR is greater than 0.7 (Fornell \& Larcker, 1981). The measures of validity are also optimal, i.e., the coefficients of standardized loadings are greater than 0.5 and their means are greater than 0.7 (Hair, Black, Babin, Anderson, \& Tatham, 2005), which confirms the convergent validity of the model. In addition, none of the confidence intervals of the correlations contains the value of 1 (Anderson \& Gerbin, 1988) and so it shows discriminant validity. We have also analyzed the correlations between constructs to verify the discriminant validity using the analysis suggested by Fornell and Larcker (1981). If the average variance extracted (AVE) is larger than the shared variance, there is discriminant validity. Table 3 shows that in all cases this condition is met. As regards the measures of goodness-of-fit, the Root Mean Square Error of Approximation (RMSEA) is less than 0.08 (Steiger, 1990), the Tucker-Lewis Index (TLI) is greater than 0.9 (Hu \& Bentler, 1999) and the Comparative Fit Index (CFI) is also greater than 0.9 (Bentler, 1992); i.e., all indicators present optimal values. The only measure of the goodness-of-fit index (GFI) that does not meet the criterion in our model is the $\chi 2$ statistic, but we do not consider it a serious limitation due to the fact that it is very sensitive to sample size (Cheung \& Rensvold, 2002) and often, in large samples, the hypothesis of goodness-of-fit of the model is rejected, even if the hypothesis test is significant (Bentler \& Bonnet, 1980). In addition, the RMSEA, which did present appropriate values, is considered the most robust goodness-of-fit index (Steiger, 1990), is one of the most informative fit indices (Diamantopoulos \& Siguaw, 2000) and is not affected by the number of items per factor and the number of factors in the model as are most of the GFIs (Cheung \& Rensvold, 2002). 
Table 3. Discriminant validity assessment: AVE and square correlations between constructs

\begin{tabular}{|l|c|c|c|c|c|}
\hline \multicolumn{1}{|c|}{ Factor } & Congruence & Credibility & $\begin{array}{c}\text { Altruism } \\
\text { attribution }\end{array}$ & CSR & $\begin{array}{c}\text { Loyalty } \\
\text { intention }\end{array}$ \\
\hline Congruence & 0.882 & 0.694 & 0.298 & 0.448 & 0.265 \\
\hline Credibility & $(0.805 ; 0.860)$ & 0.792 & 0.381 & 0.548 & 0.308 \\
\hline $\begin{array}{l}\text { Altruism } \\
\text { attribution }\end{array}$ & $(0.487 ; 0.606)$ & $(0.564 ; 0.670)$ & 0.729 & 0.314 & 0.139 \\
\hline CSR & $(0.621 ; 0.718)$ & $(0.700 ; 0.780)$ & $(0.500 ; 0.620)$ & 0.704 & 0.284 \\
\hline $\begin{array}{l}\text { Loyalty } \\
\text { intention }\end{array}$ & $(0.452 ; 0.577)$ & $(0.496 ; 0.614)$ & $(0.300 ; 0.446)$ & $(0.470 ; 0.595)$ & 0.660 \\
\hline
\end{tabular}

Note: Main diagonal (in bold) represents Average Variance Extracted (AVE). Confidence intervals $(\alpha=0.05)$ for correlations are reported below the main diagonal. Shared variances (square correlations) are reported above the main diagonal.

Before analyzing the structural relationships, the mean values of the factors of the two gender groups were compared, by means of Student's t-test, and of the four age groups, by means of an analysis of variance (ANOVA) (Hair et al., 2005). The results showed that there were no significant differences between the means ( $p>0.05$ ), so it can be affirmed that neither gender nor age influence the values of the model factors.

\subsection{Analysis of the structural relationships and hypotheses proposed}

Table 4 shows the standardized coefficients for the analysis of structural relationships that makes it possible to compare the hypotheses based on the communication medium. Both the structural model of the traditional communication medium $(\mathrm{CFI}=0.951$; $\mathrm{TLI}=0.945$; RMSEA $=0.063)$ and that of the social media $(C F I=0.935$; TLI $=0.927$; RMSEA $=0.070)$, show a good fit (Table 5).

Table 4. Evaluation of structural models and multi-group analysis (MGA)

\begin{tabular}{|l|c|c|c|c|c|}
\hline & \multicolumn{2}{|c|}{ TM } & \multicolumn{2}{c|}{ SM } & MGA \\
\hline Structural relationship & Coef. & $t^{*}$ Value & Coef. & $t^{*}$ Value & Dif. $\chi^{2}$ \\
\hline $\begin{array}{l}\text { H1. Congruence } \rightarrow \\
\text { Credibility }\end{array}$ & 0.797 & $21.46^{* * *}$ & 0.795 & $22.62^{* * *}$ & 0.206 \\
\hline H2. Congruence $\rightarrow$ CSR & 0.220 & $2.65^{* * *}$ & -0.015 & -0.21 & $6.619^{* * *}$ \\
\hline $\begin{array}{l}\text { H3. Congruence } \rightarrow \text { At- } \\
\text { tribution }\end{array}$ & 0.509 & $9.53^{* * *}$ & 0.553 & $11.80^{* * *}$ & 0.017 \\
\hline H4. Credibility $\rightarrow$ CSR & 0.279 & $4.09^{* * *}$ & 0.584 & $9.13^{* * *}$ & $12.687^{* * *}$ \\
\hline H5. Attribution $\rightarrow$ CSR & 0.167 & $3.42^{* * *}$ & 0.096 & $2.25^{* *}$ & 0.781 \\
\hline H6. CSR $\rightarrow$ Loyalty & 0.630 & $12.67^{* * *}$ & 0.479 & $7.77^{* * *}$ & $5.387^{* *}$ \\
\hline
\end{tabular}

Note: TM: Traditional media; SM: Social media; MGA: Multi-group analysis; ${ }^{*}$ : p-value $<0.1$; ${ }^{* *}$ : p-value $<0.05 ;{ }^{* *}$ : p-value $<0.01$. 
Table 5. Goodness-of-fit statistics of the hypothesized models

\begin{tabular}{|c|c|c|}
\hline & TM & SM \\
\hline CFI & 0.951 & 0.935 \\
\hline TLI & 0.945 & 0.927 \\
\hline RMSEA & 0.063 & 0.070 \\
\hline S-B $\chi^{2}$ & $600.130(\mathrm{p}=0.000)$ & $685.810(\mathrm{p}=0.000)$ \\
\hline
\end{tabular}

Note: TM: Traditional media; SM: Social media.

Measurement invariance was tested in order to ensure that the differences in the structural coefficients in the multi-group analysis did not originate from discrepancies in the measurement models for each group. The individual confirmatory factor analysis for each medium corroborates the configural invariance, with a factor structure that maintains the same number of factors in each group and fit indices similar to those obtained for the joint model shown in Table $2\left(\chi^{2}=600.130 ; \mathrm{p}=0.000\right.$; CFI $=0.951 ; \mathrm{TL}=0.945$; RMSEA $=0.063$ for the traditional medium and $\chi^{2}=685.810 ; \mathrm{p}=0.000$; CFI $=0.935 ; \mathrm{TL}=0.927$; RMSEA $=0.070$ for the social medium). Metric invariance was tested, comparing the unconstrained factor loadings model with the model with equal factor loadings in each group. A not significant increment in the $\chi^{2}$ measure was obtained, with a significance level of $\alpha=0.05\left(\chi^{2}=18.490\right.$; $\mathrm{p}=0.490$ ). Furthermore, intercepts invariance in the measurement model was also tested. A not significant increment in the $\chi^{2}$ measure was obtained after adding this additional restriction, with $\alpha=0.05\left(X^{2}=34.770 ; \mathrm{p}=0.055\right)$.

When the socially responsible activity is communicated through a traditional medium, congruence is more directly related to CSR (H2 is supported) and indirectly through corporate credibility ( $\mathrm{H} 1$ and $\mathrm{H} 4$ are supported) and altruism attribution (H3 and $\mathrm{H} 5$ are supported). If the socially responsible activity is communicated through a social medium, congruence is related only indirectly to CSR based on corporate credibility and altruism attribution, but not directly (H2 is not supported). Therefore, the results show that if the socially responsible activity is communicated through a traditional medium, the congruence of the socially responsible action has both a direct and an indirect impact through corporate credibility and altruism attribution. Conversely, when it is communicated on the social medium, the relationship is only indirect. Finally, CSR is directly related to loyalty intention in both communication media.

A multi-group analysis (MGA) was conducted to study the possible differences between the structural coefficients of the types of communication media. The causal relationships showing significant differences based on the communication medium can be seen in the column with the $\chi^{2}$ differences. The analysis confirmed the existence of significant differences in the direct causal relationship between congruence and CSR, as well as between corporate credibility and CSR, and CSR and loyalty intention. On the one hand, the direct relationship between congruence and CSR is significant in the traditional medium $(\lambda=0.220)$, but not in the social medium (H7.2 is supported); and, on the other, the relationship between credibility and CSR is of greater intensity in the social medium $(\lambda=0.584)$ than in the traditional medium ( $\lambda=0.279$ ) (H7.4 is not supported). In addition, the relationship between CSR and 
loyalty intention is stronger in the traditional medium $(\lambda=0.630)$ than in the social medium ( $\lambda=0.479$ ) (H7.6 is supported). Therefore, the results show the existence of structural differences in the causal relationships of the model based on the communication medium used to publicize the CSR activity (H7 is partially supported). In the traditional medium, the overall effect between congruence and loyalty intention based on the product of the different causal relationships has a value of 0.332 , and 0.241 in the social medium, with this latter being clearly lower. Figure 2 shows the results of the two models with their respective structural coefficients.

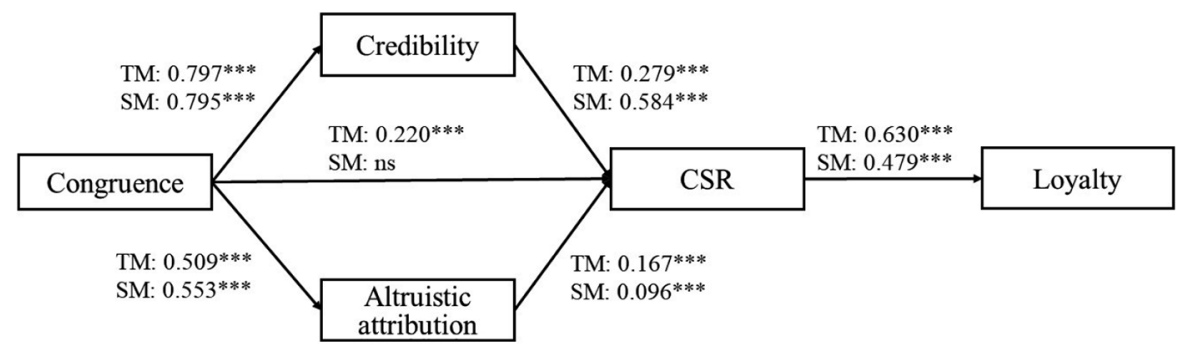

Note: TM: Traditional medium; SM: Social medium; ns: not significant; ${ }^{* * *}$ : p-value $<0.01$.

Figure 2. Traditional medium/social medium models

\section{Discussion}

\subsection{Theoretical implications}

The overall objective of this research was to help to broaden knowledge of the effect of advertising a socially responsible activity on perceived corporate social responsibility (CSR) and its impact on consumer loyalty, considering the moderating effect of the communication medium. After a comprehensive review of the literature, a model based on prior research by Rifon et al. (2004), Bigné et al. (2012) and Walsh and Bartikowski (2013) was proposed. The model includes the impact of the congruence between the company and socially responsible activity, credibility, and altruism attribution on perceived CSR. Companies want to be linked with the socially responsible activities they undertake in order to provoke associative learning that will position them as socially responsible companies (Bigné et al., 2012; Sen et al., 2016). According to the Hierarchy of Effects Model, CSR activities produce behavioral effects on the consumer, including loyalty intention (Walsh \& Bartikowski, 2013). Companies use different media to publicize their CSR activities, and their choices impact on consumer response (Jeong et al., 2013).

This study makes several important contributions to the literature on CSR. First, the results show that congruence between the activity carried out and the company's other activities has a direct impact on the consumer's perception of its CSR and an indirect effect through the credibility and altruism attributed to the company. These findings are consistent with previous studies that had shown a causal relationship between congruence and credibility (Rifon et al., 2004), the perception of CSR (Bigné et al., 2012) and altruism attribution (Marín 
et al., 2016), as well as between credibility and CSR (Korschun et al., 2014) and between attribution and CSR (Ioannou \& Serfaeim, 2015). In addition, a positive causal relationship was found between the perception of CSR and the consumer's loyalty intention, which is in line with previous studies (Walsh \& Bartikowski, 2013). Therefore, this study brings together the antecedents of perceived CSR and their influence into one outcome variable, which can be found in the response in the consumer's behavior through his or her loyalty intention.

Second, the perception of a CSR activity advertisement has a positive impact on loyalty intention regardless of the medium used to disseminate information about the CSR activity. However, the traditional medium model has a better fit and its overall effect is greater than the social medium model. These findings have not been observed previously in the literature, and therefore they represent an important contribution by this study. Specifically, significant differences were observed between the two media in three model relationships: the relationships between company-cause congruence and perceived CSR, and between CSR and loyalty, are stronger in the traditional media; on the other hand, the relationship between corporate credibility and perceived CSR is stronger in the social media.

Regarding the direct impact of congruence on CSR, the relationship is not significant in social media. The explanation for this result can be found in the relationship of the communication tool (advertising) with the medium used (newspaper or social network). In recent years, the use of social networks by companies as part of their communications strategies has been growing (Kent \& Taylor, 2016), even to the detriment of the use of traditional communications (Korschun \& Du, 2013). However, for the most part, companies usually communicate unilaterally on social media, not interactively (Etter, 2013). When unilateral communication takes place through the insertion of an advertisement, the perception of congruence may be impaired by the effect of dissonance of the medium (social media) with the communication tool (advertising). That is, considering the possible multidimensionality (i.e. functional and image) of the congruence (Bigné et al., 2012), the consumer might perceive a certain functional congruence (i.e. food company and food related cause) but not the symbolic or image congruence that would be affected by the medium (i.e. advertising in a social media).

Moreover, the influence of CSR on loyalty is significantly greater in the traditional medium. This result may be due to the fact that the positive attitude toward the company that results from the performance of socially responsible activities is reinforced by the consonance between the means used to communicate it (i.e. traditional media) and the way of doing it (i.e. an advertisement). These results are in line with the findings reported by the Nielsen Global Trust in Advertising (Nielsen, 2015). According to this publication, traditional advertising channels are still among the most trustworthy media, the great majority of the global respondents to the Nielsen survey arguing they trust advertisements on TV, in newspapers and magazines, while less than a half of the respondents said they trust advertisements on social media, even among Millenials (age 21-34). The same patterns exist for those channels consumers are more likely to use (i.e. purchase and re-purchase), TV and newspaper advertisements being the second and third most effective formats for promoting loyalty, behind only recommendations from family and friends. In addition, previous research has shown that non-interactive advertisements in social media irritate users because they see the 
medium as a channel for social, not commercial relationships, unless they present certain characteristics (e.g. participation, realization, personalization and feedback) (Dehghani \& Tumer, 2015), which are not present in the stimulus used in this study.

Finally, the effect of corporate credibility on perceived CSR is greater in social media. This result, which is contrary to that predicted, can perhaps be explained by the fact that the participants have evaluated positively that the advertisement was inserted in the company's social profile and not in the user's personal profile. The participants may have interpreted that they were encountering an online brand community, which would generate greater confidence and a better attitude toward the company (Chi, 2011). A recent study suggests that consumers believe that social networks are reliable tools for the communication of CSR activities and that such communication positively influences their attitude (Ali, JiménezZarco, \& Bicho, 2015).

\subsection{Managerial implications}

This study also has significant implications for the ways companies do business. First, companies must communicate their CSR because this improves the loyalty intention of consumers. Companies that act responsibly improve their image and the behavior of consumers towards the company. Second, companies must carry out CSR activities that fit their images because this will benefit their credibility, altruism attribution and perceived CSR. In other words, if the company is engaged in, e.g., selling food products, it must carry out activities related to these products and their markets. Finally, if the communication of the CSR activity is unilateral, from company to consumer, the traditional medium is most suitable. Still, if the company decides on one-way communication on a social medium, the company must take great care with the choice of the activity and the design of the message. This is because, in this medium, the effects will depend to a greater extent on credibility and altruism attribution than for the traditional medium.

\section{Conclusions}

This research develops a model to predict the effect of advertising a socially responsible activity on perceived corporate social responsibility (CSR) and its influence on consumer loyalty, considering the moderating effect of the medium of communication (i.e. traditional media vs. social media). The findings have five main theoretical implications. First, company-cause congruence has a direct impact on the perception of CSR and indirectly through credibility and the attribution of altruism to the company. Second, a positive causal relationship was found between the perception of CSR and the consumer's loyalty intention. Third, the traditional medium (i.e. newspaper) model has a better fit and its overall effect is greater than the social medium (i.e. social network) model. Four, the relations between company-cause congruence and perceived CSR, and between perceived CSR and loyalty, are stronger in the traditional media. Fifth, on the other hand, the relationship between corporate credibility and perceived CSR is stronger in social media. By integrating into a single model the antecedents of perceived CSR, its influence on customer loyalty intention and the moderating effect of 
the medium used to disseminate information on socially responsible activities, this study contributes to the better understanding of CSR activities and communications management.

This paper has certain limitations that affect the evaluation and generalization of the results. First, the data are from Spain, which limits the validity of the model in other countries and cultures. Second, the experiment is cross-sectional and, therefore, the evolution of the moderating effect cannot be observed over time. Third, the experiment was done by inserting an advertisement in a free newspaper and on one social network, both of which will have prior reputations, which may alter the credibility of the message and, therefore, the behavior of the consumer. Fourth, an analysis was done of the effect of unilateral communication between company-consumer, but not the communications carried out bilaterally between consumers, or the company-consumer interaction on social media. Fifth, the model included only the business-related association of CSR. Sixth, the proposed theoretical model has been tested using only a highly congruent social cause, which could influence positively on altruism attribution and credibility.

Future research could replicate the study in other countries, since socially responsible behavior can have different interpretations depending on the territory. In that case, socio demographic control covariates should be included in the model to avoid potential biases. In addition, an analysis of the dual nature of congruence (Bigné et al., 2012), and an evaluation of the effects of communication through other media, as well as consumer-consumer or company-consumer interactions (Korschun \& Du, 2013), are recommended. It would be interesting to replicate the proposed theoretical model using other products which might vary in their company-cause congruence (low and high). Finally, future papers could extend the analysis by evaluating the impact of perceived CSR on word-of-mouth.

\section{Acknowledgements}

The authors are grateful to the anonymous referees and to the Editor for their insightful comments and suggestions during the reviewing process, which were very constructive and helpful to improve the manuscript.

\section{Disclosure statement}

The authors declared no potential conflicts of interest with respect to the research, authorship, and/or publication of this article.

\section{References}

Agudo, J. M., Gargallo, P., \& Salvador, M. (2015). Measuring corporative social performance in firms: a bayesian factor analysis approach. Journal of Business Economics and Management, 16(3), 638-659. https://doi.org/10.3846/16111699.2012.745816

Ali, I., Jiménez-Zarco, A. I., \& Bicho, M. (2015). Using social media for CSR communication and engaging stakeholders. In A. Adi, G. Grigore, \& D. Crowther (Eds.), Corporate social responsibility in the digital age developments in corporate governance and responsibility (Vol. 7, pp. 165-185). Wagon Lane, UK: Emerald Group Publishing Limited. https://doi.org/10.1108/S2043-052320150000007010 
Anderson, J., \& Gerbing, D. (1988). The use of pledges to build and sustain commitment in distribution channels: a review and recommended two-step approach. Psychological Bulletin, 103, 411-423. https://doi.org/10.1037/0033-2909.103.3.411

Barone, M. J., Norman, A. T., \& Miyazaki, A. D. (2007). Consumer response to retailer use of causerelated marketing: is more fit better?. Journal of Retailing, 83(4), 437-445. https://doi.org/10.1016/j.jretai.2007.03.006

Becker-Olsen, K. L., Cudmore, B. A., \& Hill, R. P. 2006. The impact of perceived corporate social responsibility on consumer behavior. Journal of Business Research, 59(1), 46-53. https://doi.org/10.1016/j.jbusres.2005.01.001

Bentler, P. (1992). On the fit of models to covariances and methodology to the Bulletin. Psychological Bulletin, 112(3), 400-404. https://doi.org/10.1037/0033-2909.112.3.400

Bentler, P., \& Bonnet, D. (1980). Significance tests and goodness of fit in the analysis of covariance structures. Psychological Bulletin, 88, 588-606. https://doi.org/10.1037/0033-2909.88.3.588

Berens, G., van Riel, C. B. M., \& van Bruggen, G. H. (2005). Corporate associations and consumer product responses: the moderating role of corporate brand dominance. Journal of Marketing, 69, 35-48. https://doi.org/10.1509/jmkg.69.3.35.66357

Berg, K. T., \& Sheehan, K. B. (2014). Social media as a CSR communication channel: the current state of practice. In M. W. DiStaso \& D. Sevick Bortree (Eds.), Ethical practice of social media in public relations (pp. 99-110). New York: Routledge.

Bigné, E., Currás, R., \& Aldás, J. (2012). Dual nature of cause-brand fit: influence on corporate social responsibility consumer perception. European Journal of Marketing, 46(3/4), 575-594. https://doi.org/10.1108/03090561211202620

Bigné, E., Currás, R., \& Sánchez, I. (2009). Brand credibility in cause-related marketing: the moderating role of consumer values. Journal of Product \& Brand Management, 18(6), 437-447. https://doi.org/10.1108/10610420910989758

Cheung, G. W., \& Rensvold, R. B. (2002). Evaluating goodness-of-fit indexes for testing measurement invariance. Structural Equation Modeling, 9(2), 233-255. https://doi.org/10.1207/S15328007SEM0902_5

Chi, H. H. (2011). Interactive digital advertising vs. virtual brand community: exploratory study of user motivation and social media marketing responses in Taiwan. Journal of Interactive Advertising, 12(1), 44-61. https://doi.org/10.1080/15252019.2011.10722190

Cronbach, L. J. (1951). Coefficient alpha and the internal structure of tests. Psychometrika, 16(3), 297334. https://doi.org/10.1007/BF02310555

Dehghani, M., \& Tumer, M. (2015). A research on effectiveness of Facebook advertising on enhancing purchase intention of consumers. Computers in Human Behavior, 49, 597-600. https://doi.org/10.1016/j.chb.2015.03.051

Diamantopoulos, A., \& Siguaw, J. A. (2000). Introducing LISREL: a guide for the uninitiated. Sage Publications Ltd. https://doi.org/10.4135/9781849209359

Donia, M. B., \& Sirsly, C. A. T. (2016). Determinants and consequences of employee attributions of corporate social responsibility as substantive or symbolic. European Management Journal, 34(3), 232-242. https://doi.org/10.1016/j.emj.2016.02.004

Du, S., Bhattacharya, C. B., \& Sen, S. (2010). Maximizing business returns to corporate social responsibility (CSR): the role of CSR communication. International Journal of Management Reviews, 12(1), 8-19. https://doi.org/10.1111/j.1468-2370.2009.00276.x

Du, S., Bhattacharya, C. B., \& Sen, S. (2007). Reaping relational rewards from corporate social responsibility: the role of competitive positioning. International Journal of Research in Marketing, 24(3), 224-241. https://doi.org/10.1016/j.ijresmar.2007.01.001 
Ellen, P. S., Webb, D. J., \& Mohr, L. A. (2006). Building corporate associations: consumer attributions for corporate socially, Journal of the Academy of Marketing Science, 34(2), 147-157. https://doi.org/10.1177/0092070305284976

Etter, M. (2013). Reasons for low levels of interactivity: (Non-) interactive CSR communication in twitter. Public Relations Review, 39(5), 606-608. https://doi.org/10.1016/j.pubrev.2013.06.003

Folkes, V. S. (1988). Recent attribution research in consumer behavior: a review and new directions. Journal of Consumer Research, 14(4), 548-565. https://doi.org/10.1086/209135

Fornell, C., \& Bookstein, F. L. (1982). Two structural equation models: LISREL and PLS applied to consumer Exit-Voice Theory. Journal of Marketing Research, 19, 440-452. https://doi.org/10.2307/3151718

Fornell, C., \& Larcker, D. F. (1981). Structural equation models with unobservable variables and measurement error. Journal of Marketing Research, 18(1), 39-50. https://doi.org/10.2307/3151312

Golob, U., Podnar, K., Elving, W. J., Ellerup Nielsen, A., \& Thomsen, C. (2013). CSR communication: quo vadis?. Corporate Communications: an International Journal, 18(2), 176-192. https://doi.org/10.1108/13563281311319472

Green, T., \& Peloza, J. (2015). How did the recession change the communication of corporate social responsibility activities?. Long Range Planning, 48(2), 108-122. https://doi.org/10.1016/j.lrp.2014.07.004

Hair, J. F., Black, W. C., Babin, B. J., Anderson, R. E., \& Tatham, R. (2005). Multivariate data analysis. Prentice Hall: New Jersey.

Herzig, C., \& Schaltegger, S. (2006). Corporate sustainability reporting. An overview. In S. Chaltegger (Ed.), Sustainability Accounting and Reporting (pp. 301-324). Netherland: Springer.

$\mathrm{Hu}, \mathrm{L}, \&$ Bentler, P. (1999). Cutoff criteria for fit indexes in covariance structure analysis: conventional criteria versus new alternatives. Structural Equation Modeling: a Multidisciplinary Journal, 6(1), 1-55. https://doi.org/10.1080/10705519909540118

Iacobucci, D., \& Churchill, G. A. (2010). Marketing research: methodological foundations (10 ${ }^{\text {th }}$ ed.). London: South-Western.

Interactive Advertising Bureau. (2015). Estudio anual redes sociales 2015. Retrieved from http://www. iabspain.net/wpcontent/uploads/downloads/2015/01/Estudio_Anual_Redes_Sociales_2015.pdf

Información y Control de Publicaciones. (2016). Medios Controlados. Retrieved from http://www.introl. es/medios-controlados/?

Ingenhoff, D., \& Sommer, K. (2011). Corporate social responsibility communication. Journal of Corporate Citizenship, 42, 73-91. https://doi.org/10.9774/GLEAF.4700.2011.su.00007

Ioannou, I., \& Serafeim, G. (2015). The impact of corporate social responsibility on investment recommendations: analysts' perceptions and shifting institutional logics. Strategic Management Journal, 36(7), 1053-1081.

Jahdi, K. S., \& Acikdilli, G. (2009). Marketing communications and corporate social responsibility (CSR): marriage of convenience or shotgun wedding?. Journal of Business Ethics, 88(1), 103-113. https://doi.org/10.1007/s10551-009-0113-1

Jeong, H. J., Paek, H. J., \& Lee, M. (2013). Corporate social responsibility effects on social network sites. Journal of Business Research, 66, 1889-1895. https://doi.org/10.1016/j.jbusres.2013.02.010

Johnson, T., \& Kaye, B. K. (1998). Cruising is believing? Comparing internet and traditional sources on media credibility measures. Journalism and Mass Communication Quarterly, 75(2), 325-340. https://doi.org/10.1177/107769909807500208

Kantar Worldpanel. (2015). El sector de la distribución alimentaria. Retrieved from http://www.kantarworldpanel.com/es/grocery-market-share/

Kelley, H. H. (1973). The processes of causal attribution. American Psychologist, 28(2), 107-128. https://doi.org/10.1037/h0034225 
Kelly, L., Kerr, G., \& Drennan, J. (2010). Avoidance of advertising in social networking sites. Journal of Interactive Advertising, 10(2), 16-27. https://doi.org/10.1080/15252019.2010.10722167

Kent, M. L., \& Taylor, M. (2016). From Homo Economicus to Homo dialogicus: rethinking social media use in CSR communication. Public Relations Review, 42(1), 60-67.

https://doi.org/10.1016/j.pubrev.2015.11.003

Korschun, D., Bhattacharya, C. B., \& Swain, S. D. (2014). Corporte social responsibility, customer orientation, and the job performance of frontline employees. Journal of Marketing, 78(3), 20-37. https://doi.org/10.1509/jm.11.0245

Korschun, D., \& Du, S. (2013). How virtual corporate social responsibility dialogs generate value: a framework and propositions. Journal of Business Research, 66, 1494-1504. https://doi.org/10.1016/j.jbusres.2012.09.011

Lafferty, B. (2007). The relevance of fit in a cause-brand alliance when consumers evaluate corporate credibility. Journal of Business Research, 60(5), 447-453. https://doi.org/10.1016/j.jbusres.2006.09.030

Lavidge, R. J., \& Steiner, G. A. (1961). A model for predictive measurements of advertising effectiveness. Journal of Marketing, 24, 59-62. https://doi.org/10.2307/1248516

Leonidou, C. N., \& Skarmeas, D. (2017). Gray shades of green: causes and consequences of green skepticism. Journal of Business Ethics, 144(2), 401-415. https://doi.org/10.1007/s10551-015-2829-4

Maignan, I., \& Ferrell, O. C. (2004). Corporate social responsibility and marketing: an integrative framework. Journal of the Academy of Marketing Science, 32(1), 3-19. https://doi.org/10.1177/0092070303258971

Marín, L., Cuestas, P., \& Román, S. (2016). Determinants of consumer attributions of corporate social responsibility. Journal of Business Ethics, 138(2), 247-260. https://doi.org/10.1007/s10551-015-2578-4

Martindale, C. (1991). Cognitive psychology: a neural-network approach. Pacific Grove, CA: Brooks/ Cole Publishing Company.

McWilliams, A., \& Siegel, D. (2001). Corporate social responsibility: a theory of the firm perspective. Academy of Management Review, 26(1), 117-127. https://doi.org/10.5465/amr.2001.4011987

Mercadé-Melé, P., Molinillo-Jiménez, S., \& Fernández-Morales, A. (2014). Influencia de las prácticas de responsabilidad social corporativa en la actitud del consumidor: análisis comparado de Mercadona, Carrefour y Eroski. Revista de Empresa Familiar, 4(1), 73-88.

Mercadé-Melé, P., Molinillo, S., \& Fernández-Morales, A. (2017). The influence of the types of media on the formation of perceived CSR. Spanish Journal of Marketing-ESIC, 21, 54-64. https://doi.org/10.1016/j.sjme.2017.04.003

Moore, J. J., \& Rodgers, S. L. (2005). An examination of advertising credibility and skepticism in five different media using the persuasion knowledge model. In American Academy of Advertising Conference Proceedings, January 1, Houston (pp. 10-18). Pullman, WA: American Academy of Advertising.

Murray, K. B., \& Vogel, C. M. (1997). Using a hierarchy-of-effects approach to gauge the effectiveness of corporate social responsibility to generate goodwill toward the firm: financial versus nonfinancial impacts. Journal of Business Research, 38(2), 141-160. https://doi.org/10.1016/S0148-2963(96)00061-6

Nan, X., \& Heo, K. (2007). Consumer responses to corporate social responsibility (CSR) initiatives: examining the role of brand-cause fit in cause-related marketing. Journal of Advertising, 36(2), 6374. https://doi.org/10.2753/JOA0091-3367360204

Nguyen, N., \& Leblanc, G. (2001). Corporate image and corporate reputation in customers' retention decisions in services. Journal of Retailing and Consumer Services, 8(4), 227-236. https://doi.org/10.1016/S0969-6989(00)00029-1

Nielsen, A. C. (2015). Global trust in advertising: a Nielsen Report. NY: USA, ACNielsen. 
Oliver, R. L. (1999). Whence consumer loyalty?. Journal of Marketing, 63, 33-44. https://doi.org/10.2307/1252099

Oppewal, H., Alexander, A., \& Sullivan, P. (2006). Consumer perceptions of corporate social responsibility in town shopping centres and their influence on shopping evaluations. Journal of Retailing and Consumer Services, 13, 261-274. https://doi.org/10.1016/j.jretconser.2005.08.015

Peloza, J., \& Shang, J. (2011). How can corporate social responsibility activities create value for stakeholders? A systematic review. Journal of the academy of Marketing Science, 39(1), 117-135. https://doi.org/10.1007/s11747-010-0213-6

Pérez, A., \& Rodríguez Del Bosque, I. (2015). An integrative framework to understand how CSR affects customer loyalty through identification, emotions and satisfaction. Journal of Business Ethics, 129(3), 571-584. https://doi.org/10.1007/s10551-014-2177-9

Pollach, I. (2005). Corporate self-presentation on the www: strategies for enhancing usability, credibility and utility. Corporate Communications: an International Journal, 10(4), 285-301. https://doi.org/10.1108/13563280510630098

Porter, M., \& Kramer, M. (2011). Created shared value. Harvard Business Review, 89(1/2), 62-77.

Rifon, N., Choi, S., Trimble, C., \& Li, H. (2004). Congruences effects in sponsorship: the mediating role of sponsor credibility and consumer attributions of sponsor motive. Journal of Advertising, 33(1), 29-42. https://doi.org/10.1080/00913367.2004.10639151

Saat, R. M., \& Selamat, M. H. (2014). An examination of consumer's attitude towards corporate social responsibility (CSR) web communication using media richness theory. Procedia-Social and Behavioral Sciences, 155, 392-397. https://doi.org/10.1016/j.sbspro.2014.10.311

Sen, S., Du, S., \& Bhattacharya, C. B. (2016). Corporate social responsibility: a consumer psychology perspective. Current Opinion in Psychology, 10, 70-75. https://doi.org/10.1016/j.copsyc.2015.12.014

Shimp, T. A., Stuart, E. W., \& Engle, R. W. (1991). A program of classical conditioning experiments testing variations in the conditioned stimulus and context. Journal of Consumer Research, 18(1), 1-12. https://doi.org/10.1086/209236

Sirohi, N., McLaughlin, E. W., \& Wittink, D. R. (1998). A model of consumer perceptions and store loyalty intentions for a supermarket retailer. Journal of Retailing, 74(2), 223-245. https://doi.org/10.1016/S0022-4359(99)80094-3

Skard, S., \& Thorbjørnsen, H. (2014). Is publicity always better than advertising? The role of brand reputation in communicating corporate social responsibility. Journal of Business Ethics, 124(1), 149160. https://doi.org/10.1007/s10551-013-1863-3

Skarmeas, D., \& Leonidou, C. N. (2013). When consumers doubt, watch out! The role of CSR skepticism. Journal of Business Research, 66(10), 1831-1838. https://doi.org/10.1016/j.jbusres.2013.02.004

Steiger, J. (1990). Structural model evaluation and modification: an interval estimation approach. Multivariate Behavioral Research, 25, 173-180. https://doi.org/10.1207/s15327906mbr2502_4

Susnienè, D., \& Purvinis, O. (2015). Empirical insights on understanding stakeholder influence. Journal of Business Economics and Management, 16(4), 845-860.

https://doi.org/10.3846/16111699.2013.785974

Till, B. D., \& Nowak, L. I. (2000). Toward effective use of cause-related marketing alliances. The Journal of Product and Brand Management, 9(7), 472-484. https://doi.org/10.1108/10610420010351394

Vaaland, T. I., Heide, M., \& Grønhaug, K. (2008). Corporate social responsibility: investigating theory and research in the marketing context. European Journal of Marketing, 42(9/10), 927-953. https://doi.org/10.1108/03090560810891082

Varadarajan, P. R., \& Menon, A. (1988). Cause-related marketing: acoalignment of marketing strategy and corporate philanthropy. Journal of Marketing, 52(3), 58-74.

https://doi.org/10.2307/1251450 
Vlachos, P. A. (2012). Corporate social performance and consumer-retailer emotional attachment. The moderating role of individual traits. European Journal of Marketing, 46(11/12), 1559-1580. https://doi.org/10.1108/03090561211259989

Walsh, G., \& Bartikowski, B. (2013). Exploring corporate ability and social responsibility associations as antecedents of customer satisfaction cross-culturally. Journal of Business Research, 66, 989-995. https://doi.org/10.1016/j.jbusres.2011.12.022

Wanderley, L. S. O., Lucian, R., Farache, F., \& de Sousa Filho, J. M. (2008). CSR information disclosure on the web: a context-based approach analysing the influence of country of origin and industry sector. Journal of Business Ethics, 82(2), 369-378. https://doi.org/10.1007/s10551-008-9892-z

Wang, H., Tong, L., Takeuchi, R., \& George, G. (2016). Corporate social responsibility: an overview and new research directions. Academy of Management Journal, 59(2), 534-544.

https://doi.org/10.5465/amj.2016.5001 


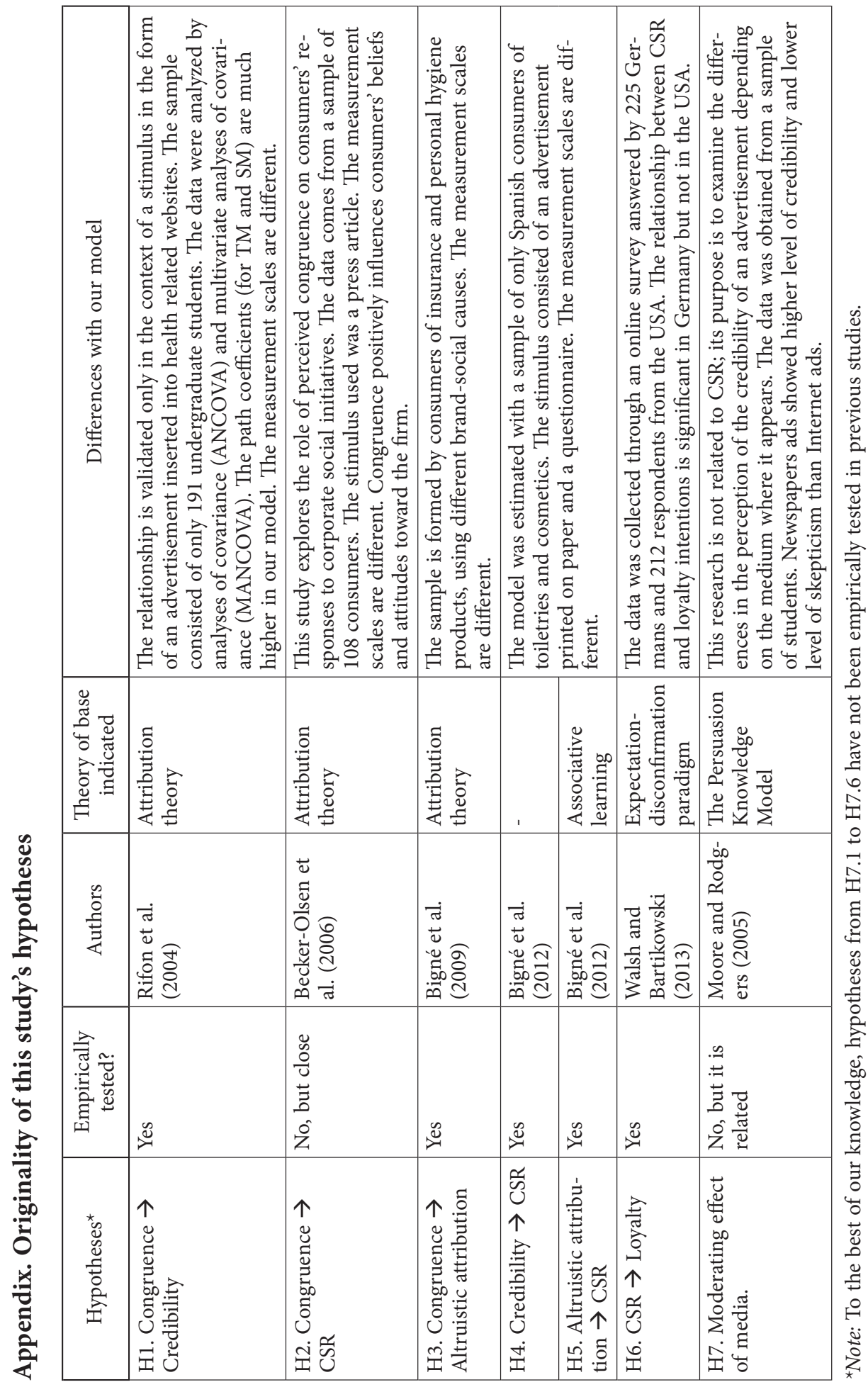

